\title{
Antioxidant and Oxygen Radical Scavenging Capacities of the Extracts of Pear Cactus, Mulberry and Korean Black Raspberry Fruits
}

\author{
Joonhee Lee', Jung-Bin Whang', Na-Ri Youn ${ }^{2}$, Sun-Young Lee ${ }^{2}$, Hyang-Jung Lee ${ }^{2}$, \\ Young-Jun Kim ${ }^{3,4}$, and Kyung-Hee $\mathrm{Koh}^{2 \dagger}$ \\ ${ }^{1}$ Health Metrology Center, Division of Quality of Life, Korea Research Institute \\ of Standards and Science (KRISS), Daejeon 305-340, Korea \\ ${ }^{2}$ Department of Food Science and Nutrition, The Catholic University of Korea, \\ Gyeonggi 420-743, Korea \\ ${ }^{3}$ Department of Agricultural Biotechnology, Seoul National University, Seoul 151-921, Korea and \\ ${ }^{4} R \& D$ Food Safety Center, OTTOGI Corporation, Gyeonggi 431-070, Korea
}

\begin{abstract}
In this study, we evaluated the phytochemical compositions of the fruits of the pear cactus, mulberry, and Korean black raspbery to determine how they related to antioxidant capacity. Specifically, the total soluble polyphenol, flavonoid and anthocyanin contents were determined, and the phenolic compounds were evaluated by HPLC. In addition, the antioxidant capacity was evaluated by electron paramagnetic resonance (EPR), SOD-like activity and nitrate scavenging activity. Korean black raspbery was found to have the highest level of phytochemicals, followed by mulbery and pear cactus $(p<0.05)$. Furthermore, EPR revealed that Korean black raspberry extract $(100 \mu \mathrm{g} / \mathrm{mL})$ removed $78.6 \%$ of the superoxide radicals in a xanthin-xanthin oxidase. Additionally, when the removal of hydroxyl radicals was evaluated, the extract of pear cactus showed $50 \%$ scavenging activity at $1000 \mu \mathrm{g} / \mathrm{mL}$. Korean black raspberry extract showed the highest SOD-like activity, which was $44 \%$ (p<0.05). Finally, the nitrate scavenging activity of both extracts of mulberry and Korean black raspberry were found to be $93 \%$, while that of the pear cactus was $63 \%$ at $\mathrm{pH} 1.2(\mathrm{p}<0.05)$.
\end{abstract}

Key words: fruits, antioxidants, total soluble phenolics, total flavonoids, electron paramagnetic resonance

\section{INTRODUCTION}

A large number of epidemiological studies have revealed that consumption of a high number of antioxidant-rich fruits and vegetables is inversely correlated with the incidence of cancer $(1,2)$. For example, Lee and Lee (3) reported that a low risk of cancer was more closely related to a diet rich in multiple antioxidants than a diet supplemented with individual antioxidant. Phytochemical compounds in several fruits and vegetables, including polyphenols, anthocyanins, flavonoids and phenolic acids, are best known for their antioxidant and antiradical capacities. Indeed, it has been reported that polyphenolic antioxidants prevent skin damage (4), aging (5) and Alzheimer's and Parkinson's diseases $(5,6)$ via their ability to quench reactive oxygen species and through protection of critical cellular components such as DNA, proteins and lipids from oxidative stress (7).

Recently, the pharmacological effects of fruits of the mulberry tree (Odi, in Korean), pear cactus (Baknyuncho, in Korean) and Korean black raspberry plant (Bokbunja, in Korean), which are used in traditional medicine, were evaluated. Mulberry trees are primarily used as sources of leaves to raise silkworms; however, their leaves, bark and branches have long been used in Chinese medicine to treat fever, protect the liver, strengthen joints and lower blood pressure (8). Consumption of the fruit of the mulberry tree has recently increased because it is known to contain phenolic compounds such as anthocyanins, which inhibit the development of atherosclerosis (9) and the growth of cancer cells (10). The pear cactus belongs to the Cactaceae family and is well adapted to arid and semiarid climates (11). Pear cacti are usually consumed fresh, and have recently been used in a wide variety of foods and cosmetic products due to their antioxidant activity. In addition, the pear cactus was recently shown to have anti-diabetic (12), anti-inflammatory (13) and analgesic (14) activities. Korean black raspberry is distributed in limited areas in Southeast Asian countries such as southern parts of the Korean peninsula, China and Japan (15). Korean black raspberry has traditionally been consumed as fresh fruits, jam, jelly and in non-alco-

${ }^{\dagger}$ Corresponding author. E-mail: verokoh@catholic.ac.kr

Phone: +82-2-2164-4313, Fax: +82-2-2164-4310 
holic beverages. Recently, Korean black raspberry has been utilized to produce alcoholic beverages and health-promoting products due to its distinctive quality and medicinal activities such as anti-inflammatory (16), anti-cancer and anti-anaphylactic effects (12).

The purpose of the present study was to compare the superoxide anion and hydroxyl radical scavenging properties of pear cactus, mulberry and Korean black raspberry fruit extracts by electron spin resonance (ESR). In addition, the relationship between phenolic compounds present in fruits and their antioxidant activities was evaluated.

\section{MATERIALS AND METHODS}

\section{Fruit material and extraction}

Freeze dried pear cactus (Opuntia ficus-indica, OF), mulberry (Morus alba L., MF) and Korean black raspberry (Rubus coreanus Miq., RF) fruits were purchased from local markets. Samples $(100 \mathrm{~g})$ of each fruit were ground with grinder (FM-909T Shinhan Electric, Korea) for $2 \mathrm{~min}$, after which they were kept in an air-tight container at $-15^{\circ} \mathrm{C}$ until further use.

To assess the total soluble phenolic contents and radical scavenging activity, the phytochemicals in the ground samples $(50 \mathrm{~g})$ were extracted three times with $70 \%$ ethanol $(250 \mathrm{~mL})$ for $1 \mathrm{hr}$ in a mechanical shaker at room temperature (17). The extract was then filtered through Whatman \#1 filter paper, after which the residue on the filter paper was extracted three times. The yields of the extract of the pear cactus, mulberry and Korean black raspberry were $94.3 \%, 95.3 \%$ and $94 \%$, respectively. The ethanol extracts were kept at $3{ }^{\circ} \mathrm{C}$ until chemical analyses were conducted.

\section{Total soluble phenolic contents}

The total soluble phenolic contents were determined using the Folin-Ciocalteu method (18). Briefly, each extract $(100 \mu \mathrm{L})$ was mixed with $6 \mathrm{~mL}$ of distilled water and $0.5 \mathrm{~mL}$ of Folin-Ciocalteu's reagent and then allowed to react for 30 seconds, after which $1.5 \mathrm{~mL}$ of saturated $\mathrm{Na}_{2} \mathrm{CO}_{3}$ solution was added. The mixture was then kept at room temperature for $2 \mathrm{hr}$, after which its absorbance was measured at $765 \mathrm{~nm}$. Data were expressed as gallic acid equivalents (GAE, mg/100 g).

\section{Total flavonoid contents}

The total flavonoids were assessed based on the absorbance at $415 \mathrm{~nm}$ after being allowed to react with 10 -fold diluted extracts $(0.5 \mathrm{~mL}), 10 \%$ aluminum nitrate $(0.1 \mathrm{~mL}), 1 \mathrm{M}$ potassium acetate $(0.1 \mathrm{~mL})$ and $70 \%$ ethanol $(4.3 \mathrm{~mL})$ for $40 \mathrm{~min}(19)$. Data were expressed as quercetin equivalents $(\mathrm{mg} / 100 \mathrm{~g})$.

\section{Total anthocyanin contents}

The anthocyanin contents were determined using the methods described by Fuleki et al. (19) and Jeong (20). Briefly, each ground sample $(3 \mathrm{~g})$ was extracted with $15 \mathrm{~mL}$ of ethanol: $\mathrm{HCl}(85: 15)$ for $3 \mathrm{~min}$ in a mechanical shaker at room temperature, after which they were kept in an air-tight container for $5 \mathrm{hr}$ at $4^{\circ} \mathrm{C}$. The mixture was then centrifuged at $14,000 \times g$ and $4^{\circ} \mathrm{C}$, after which the absorbance was measured at $535 \mathrm{~nm}$. All data were expressed as the anthocyanin content (mg/100 g).

\section{HPLC analysis of phenolic compounds}

To remove the influence of anthocyanin on the HPLC analysis, non-anthocyanin phenolic compounds in the powered fruit samples $(100 \mathrm{~g})$ were extracted using 100 $\mathrm{mL}$ of ethyl acetate. The organic solvent was then evaporated to dryness under reduced pressure after the residual water was removed using sodium sulfate. Next, the extracts were redissolved in $10 \mathrm{~mL}$ of solvent $(0.2 \mathrm{M}$ phosphate buffer, $\mathrm{MeOH}: \mathrm{H}_{2} \mathrm{O}, 2: 3: 15, \mathrm{v} / \mathrm{v} / \mathrm{v}$ ) and adjusted to $\mathrm{pH} 3$ with $0.2 \mathrm{M}$ phosphate buffer for instrumental analysis (21). The phenolic compounds in the extracts were then determined by HPLC using a photodiode array detector set to $280 \mathrm{~nm}$ (Agilent 1100 series, Hewlett Packard Co., USA). The separation was conducted on a Hypersil ODS column $(250 \mathrm{~mm} \times 4.6 \mathrm{~mm}$, Hewlett Packard Co., USA) and all extracts were filtered through a $0.45 \mu \mathrm{m}$ filter prior to analysis. The elution solvents used were acetonitrile : acetic acid : methanol: $\mathrm{H}_{2} \mathrm{O}(113$ : $5: 20: 862, \mathrm{v} / \mathrm{v} / \mathrm{v} / \mathrm{v})$. The flow rate was $1.0 \mathrm{~m} / \mathrm{min}$ and 20 $\mu \mathrm{L}$ of each sample were injected. All phenolics were identified by comparing the UV/VIS spectral properties and retention times to those of authentic standards.

\section{EPR analysis}

The superoxide anion radical and hydroxyl radical scavenging activities of the samples were evaluated using an electron paramagnetic resonance (EPR) spectrometer (JEOL-JES-TES 200, Japan). Briefly, ethanolic samples were prepared in phosphate buffer at concentrations of 50 and $100 \mu \mathrm{g} / \mathrm{mL}$. The superoxide anion radical scavenging activity was then determined using a xanthin-xanthin oxidase superoxide anion generating system. Briefly, eight microliters of xanthine $(1 \mathrm{mM})$ were placed in a test tube, after which $185 \mu \mathrm{L}$ of potassium phosphate buffer $(0.1 \mathrm{M}, \mathrm{pH}$ 7.4) containing various concentration of the samples, $2 \mu \mathrm{L}$ of diethylene triamine pentaacetic acid (DTPA, $50 \mathrm{mM}$ ), $2 \mu \mathrm{L}$ of 5 , 5-dimethyl-1-pyrroline N-oxide (DMPO, $180 \mathrm{mM}$ ), $1 \mu \mathrm{L}$ of catalase $(1 \mu \mathrm{M})$ and $2 \mu \mathrm{L}$ of xanthin oxidase were added successively $(22,23)$. The hydroxyl radical scavenging activity was then measured using a Fenton re- 
action system containing $4 \mu \mathrm{L}$ of ethylene diamine tetraacetic acid (EDTA, $200 \mu \mathrm{M}), 2 \mu \mathrm{L}$ of DMPO $(90 \mathrm{mM})$, $4 \mu \mathrm{L}$ of $\mathrm{FeSO}_{4}(200 \mu \mathrm{M})$ and $5 \mu \mathrm{L}$ of $\mathrm{H}_{2} \mathrm{O}_{2}(1 \mu \mathrm{M})$ in $185 \mu \mathrm{L}$ of potassium phosphate buffer $(0.1 \mathrm{M}, \mathrm{pH}$ 7.4) that already contained various concentrations of the samples (24). EPR measurements were made after incubating the samples for $2 \mathrm{~min}$ at $20^{\circ} \mathrm{C}$. The radical scavenging activity was determined by measuring the reduction in the heights of the peaks for either the superoxide anion or the hydroxyl radical of samples to those of the control, and was calculated as follows: radical scavenging activity $(\%)=100-\left(\mathrm{A}_{1} / \mathrm{A}_{0}\right) \times 100$, where $\mathrm{A}_{0}$ was the control peak height and $A_{1}$ was the sample peak height.

\section{Superoxide dismutase (SOD)-like and nitrite scaveng- ing activity}

The SOD-like activity was determined by measuring the ability of samples to inhibit pyrogallol autoxidation using a modified version of the method described by Marklund and Marklund (25). Briefly, the samples $(0.2$ $\mathrm{mL}$ ) were added to $0.2 \mathrm{~mL}$ of pyrogallol $(7.2 \mathrm{mM})$ and $3 \mathrm{~mL}$ of Tris-HCl buffer $(50 \mathrm{mM}$, pH 8.5) that contained $10 \mathrm{mM}$ EDTA. The reaction was stopped by adding 1 $\mathrm{mL}$ of $\mathrm{HCl}(1 \mathrm{~N})$ after $10 \mathrm{~min}\left(25^{\circ} \mathrm{C}\right)$, after which the absorbance was measured at $420 \mathrm{~nm}$. The SOD-like activity (\%) was expressed as follows: SOD-like activity $(\%)=100-\left[\left\{\left(\mathrm{A}_{2}-\mathrm{A}_{1}\right) / \mathrm{A}_{0}\right\} \times 100\right]$, where $\mathrm{A}_{0}$ was the absorbance of the control, $A_{1}$ was the absorbance of the sample without reagent and $\mathrm{A}_{2}$ was the absorbance of the sample with reagent. The nitrite scavenging activity was measured using a modified version of the colorimetric method described by Kato et al. (26) and Lim et al. (27) using Griess reagent. Briefly, the ethanol extracts $(1 \mathrm{~mL})$ were added to $2 \mathrm{~mL}$ of $\mathrm{NaNO}_{2}(1 \mathrm{mM})$ and then adjusted to $\mathrm{pH}$ levels of 1.2 and 3.0 using 0.1 $\mathrm{N} \mathrm{HCl}$ and $0.2 \mathrm{M}$ citric acid. Each mixture was then diluted to $10 \mathrm{~mL}$ with buffers and kept at $37^{\circ} \mathrm{C}$ for 1 hr. Next, $1 \mathrm{~mL}$ of the mixture was reacted with $2 \mathrm{~mL}$ of $2 \%$ acetic acid and $0.4 \mathrm{~mL}$ of Griess reagent for 15 min at room temperature. The color intensity at $520 \mathrm{~nm}$ was then measured using a spectrophotometer, after which the activity was expressed as the nitrite scavenging activity $(\%)=100-\left[\left\{\left(\mathrm{A}_{2}-\mathrm{A}_{1}\right) / \mathrm{A}_{0}\right\} \times 100\right]$, where $\mathrm{A}_{0}$ was the absorbance of the control, $A_{1}$ was the absorbance of the sample without Griess reagent and $\mathrm{A}_{2}$ was the absorbance of the sample with Griess reagent.

\section{Antioxidant activity in a linoleic acid system}

The lipid peroxidation inhibitory effects of the fruits were determined using the method described by Osawa and Namiki, with slight modifications (28). Briefly, four $\mathrm{mL}$ samples in $99.9 \%$ ethanol were mixed with $4.1 \mathrm{~mL}$ of linoleic acid (2.51\%) in $99.9 \%$ ethanol, $8 \mathrm{~mL}$ of phosphate buffer $(0.05 \mathrm{M}, \mathrm{pH} 7.0)$ and $3.9 \mathrm{~mL}$ of distilled water and then kept in screw cap containers under dark conditions at $40^{\circ} \mathrm{C}$. Next, $0.1 \mathrm{~mL}$ of this solution was amended with $9.7 \mathrm{~mL}$ of $70 \%$ ethanol and $0.1 \mathrm{~mL}$ of $30 \%$ ammonium thiocyanate. Exactly $3 \mathrm{~min}$ after the addition of $0.1 \mathrm{~mL}$ of $2 \times 10^{-2} \mathrm{M}$ ferrous chloride in $3.5 \%$ hydrochloric acid to the reaction mixture, the absorbance was measured at $500 \mathrm{~nm}$. The absorbance was then measured every $24 \mathrm{hrs}$ until one day after the absorbance of the control reached its maximum. The control and standard were subjected to the same procedure as the samples, except either water or $5 \mathrm{mg}$ of $\alpha$-tocopherol were added instead of sample. The antioxidant activity was then calculated as the antioxidant activity $(\%)=100$ $-\left(A_{1} / A_{0}\right) \times 100$, where $A_{0}$ was the absorption of the control reaction index $\mathrm{x}_{\mathrm{t}=\mathrm{maxhr}}$ and $\mathrm{A}_{1}$ was the absorption in the presence of the sample reaction index $\mathrm{x}_{\mathrm{t}-\mathrm{maxh}}$. All analyses were conducted in triplicate and the mean values were calculated.

\section{Statistical analysis}

All data shown represent the means of triplicate analyses. Analysis of variance and Pearson's correlation tests were conducted using the JMP5 software (29) and the separation of the means was evaluated using Duncan's test $(\mathrm{p}<0.05)$.

\section{RESULTS AND DISCUSSION}

\section{Phytochemical analysis}

The total soluble phenolics of samples were evaluated using Folin-Ciocalteau reagent and were quantified as gallic acid equivalents. In the present study, the contents of the total soluble phenolics were as follows: Korean black raspberry $(2717.2 \pm 22.4 \mathrm{mg} / 100 \mathrm{~g})>$ mulberry $(2027.4 \pm 18.5 \mathrm{mg} / 100 \mathrm{~g})>$ pear cactus $(1209.5 \pm 33.9$ $\mathrm{mg} / 100 \mathrm{~g}$ ). A similar pattern was observed when the total flavonoids and total anthocyanins were observed. These analyses revealed that all three fruits have the potential to be good sources of flavonoids and anthocyanins due to the high contents of flavonoids and total anthocyanins, which ranged from $172.8 \sim 385.7 \mathrm{mg} / 100 \mathrm{~g}$ and $466.1 \sim 516.7 \mathrm{mg} / 100 \mathrm{~g}$, respectively (Table 1 ). All three fruits have long been consumed as fresh fruits and used as traditional folk medicines due to their beneficial effects on diabetes and heart disease. Recently, various studies were conducted to determine the ability of these fruits to be used as functional foods or cosmetic materials. Lin and Tang (30) demonstrated that there were abundant polyphenolic compounds in mulberry fruits that possessed immuno-modulatory potential that 
Table 1. Concentrations of total soluble phenolics, total flavonoids, and total anthocyanins in the extracts of pear cactus, mulberry, and black raspberry

\begin{tabular}{lccc}
\hline & $\begin{array}{c}\text { Total soluble phenolics } \\
(\mathrm{GAE}, \mathrm{mg} / 100 \mathrm{~g})^{1)}\end{array}$ & $\begin{array}{c}\text { Total flavonoids } \\
(\mathrm{mg} / 100 \mathrm{~g})^{2)}\end{array}$ & $\begin{array}{c}\text { Total anthocyanins } \\
(\mathrm{mg} / 100 \mathrm{~g})^{3)}\end{array}$ \\
\hline Pear cactus & $1209.5 \pm 33.9^{4)}$ & $172.8 \pm 9.8$ & $466.1 \pm 0.58$ \\
Mulberry & $2027.4 \pm 18.5$ & $336.3 \pm 5.8$ & $487.5 \pm 0.58$ \\
Black raspberry & $2717.2 \pm 22.4$ & $385.7 \pm 0.2$ & $516.7 \pm 0.58$ \\
\hline
\end{tabular}

${ }^{1)}$ Expressed in gallic acid equivalent. ${ }^{2)}$ Expressed in quercetin equivalent. ${ }^{3)}$ Expressed in cyanidin equivalent. ${ }^{4)}$ Mean \pm SEM.

occurred via stimulation of the proliferation of spolenocytes. In addition, anthocyanins such as cyanidin are likely to be active compounds that inhibit the development of atherosclerosis (9) and reduce the invasiveness of cancer cells (10). The presence of phenolic compounds in fruit is important in terms of their functional and nutritional evaluation.

\section{Phenolic compounds analysis}

The presence of phenolic compounds in fruit is important in terms of their functional and nutritional evaluation. Individual phenolic compounds are known to vary greatly among the fruits varieties evaluated in this study. Specifically, kaempherol, quercetin and isorhamnetin have been found in pear cactus (31), while quercetin, dehydroquercetin, morin, isoquercitrin, rutin (32-34), genistic acid, catechin, $p$-hydroxybenzoic acid, chlorogenic acid, caffeic acid, syringic acid and p-coumaric acid were identified in mulberry and Korean black raspberry $(35,36)$. In this assay, the levels of phenolic compounds in the pear cactus occurred in the following order: syringic acid $(0.34 \mathrm{mg} \%)>$ proctocatechuic acid $(0.23 \mathrm{mg} \%)>$ caffeic acid $(0.17 \mathrm{mg} \%)>$ ferulic acid $(0.16 \mathrm{mg} \%)$, while those of the mulberry were in the order of protocatechuic acid $(2.85 \mathrm{mg} \%)>$ rutin $(1.5$ $\mathrm{mg} \%)>$ chlorogenic acid $(0.31 \mathrm{mg} \%)>$ caffeic acid $(0.20 \mathrm{mg} \%)>$ syringic acid $(0.20 \mathrm{mg} \%)$, and those of the Korean black raspberry were in the order of protocatechuic acid $(3.09 \mathrm{mg} \%)>$ catechin $(3.05 \mathrm{mg} \%)>$ epicatechin $(2.39 \mathrm{mg} \%)>$ gallic acid $(1.42 \mathrm{mg} \%)>p$-coumaric acid $(0.44 \mathrm{mg} \%)>$ syringic acid $(0.29 \mathrm{mg} \%)$ (Table 2).

\section{Superoxide anion and hydroxyl radical scavenging activities}

Superoxide anion and hydroxyl and hydrogen peroxide radicals are categorized as reactive oxygen species (ROS) and are associated with cell damage that leads to aging or chronic diseases. In this study, EPR analysis was conducted to assess the potential free radical scavenging activities of fruit, namely the pear cactus, mulberry and Korean black raspberry. All three fruits were found to remove superoxide radicals (Fig. 1), but only
Table 2. Concentrations of phenolic compounds analyzed by HPLC in the extracts of pear cactus, mulberry and black raspberry

(mg\%)

\begin{tabular}{lccc}
\hline & Pear cactus & Mulberry & Black raspberry \\
\hline Gallic acid & - & - & $1.42 \pm 0.01$ \\
Protocatechuic acid & $0.23 \pm 0.00^{1)}$ & $2.85 \pm 0.03$ & $3.09 \pm 0.02$ \\
Catechin & - & - & $3.05 \pm 0.05$ \\
Chlorogenic acid & - & $0.31 \pm 0.00$ & - \\
Caffeic acid & $0.17 \pm 0.00$ & $0.20 \pm 0.02$ & - \\
Epicatechin & - & - & $2.39 \pm 0.02$ \\
Syringic acid & $0.34 \pm 0.01$ & $0.20 \pm 0.00$ & $0.29 \pm 0.00$ \\
$p$-Courmaric acid & - & $0.08 \pm 0.00$ & $0.44 \pm 0.00$ \\
Ferulic acid & $0.16 \pm 0.00$ & - & - \\
Rutin & - & $1.50 \pm 0.01$ & - \\
\hline
\end{tabular}

${ }^{1)}$ Mean \pm SEM.

the pear cactus and Korean black raspberry fruits scavenged hydroxyl radicals (Fig. 2). In addition, the superoxide anion radical scavenging activities were found to increase in all extracts in a concentration-dependent manner. Korean black raspberry extract showed the highest antioxidant activity, with a value of $79 \%$ being observed at a concentration of $100 \mu \mathrm{g} / \mathrm{mL}$, which was almost twice as high as the activity observed when 10 $\mu \mathrm{g} / \mathrm{mL}$ of quercetin were evaluated. Moreover, 20 and $50 \mu \mathrm{g} / \mathrm{mL}$ of Korean black raspberry extracts showed good antioxidant activities of 62 and $61 \%$, respectively. The antioxidant potentials of Korean black raspberry were demonstrated by its radical scavenging abilities, retardation of lipid oxidation and iron ion-chelating characteristics (37). Mulberry fruits were found to successfully remove radicals as indicated by the superoxide radical scavenging activities of 38 and $51 \%$ that were observed when the extracts were tested at concentrations of 50 and $100 \mu \mathrm{g} / \mathrm{mL}$, respectively. Pear cactus extracts also showed scavenging activities that ranged from 8.33 $\sim 33.3 \mu \mathrm{g} / \mathrm{mL}$. The superoxide radical scavenging activities of prepared fruit extracts were determined to be highly influenced by the concentrations of total anthocyanins as indicated by the good correlations $\left(\mathrm{R}^{2}>0.99\right)$ observed by Pearson correlation analysis.

The hydroxyl radical scavenging activities were also determined in the Fenton reaction system by measuring the EPR. Overall, the intensity of the hydroxyl radical 
(A)

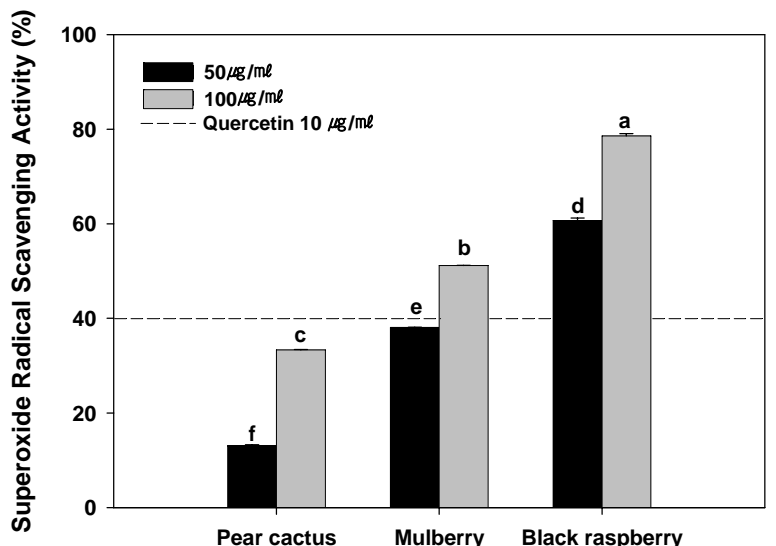

(B)

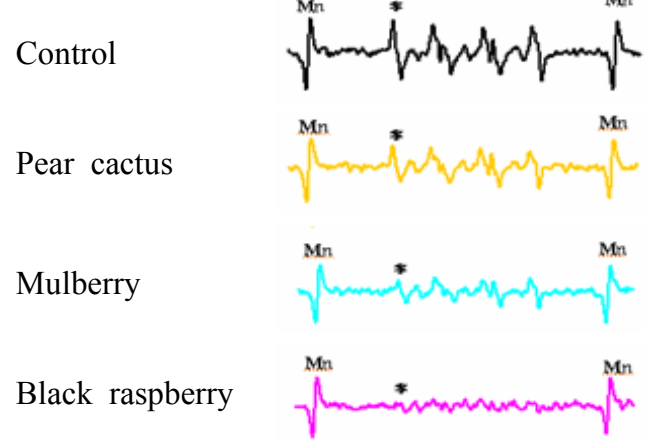

Fig. 1. Superoxide radicals scavenging activity $(\%)$ of the ethanolic extracts of fruits at various concentrations $(50,100$ $\mu \mathrm{g} / \mathrm{mL})$ as compared to that of quercetin standard $(10 \mu \mathrm{g} / \mathrm{mL})$ (A) and according to electron paramagnetic resonance (EPR) spectra at $100 \mu \mathrm{g} / \mathrm{mL}$ (B). Samples with the same letters are not significantly different (LSD test, $\mathrm{p}<0.05$ ). The conditions of EPR analysis: microwave frequency $9.42[\mathrm{GHz}]$, microwave power $5[\mathrm{~mW}]$, modulation amplitude $0.1[\mathrm{mT}]$. Asterisks $\left(^{*}\right)$ indicate the peak of DMPO-OOH.

scavenging activity was lower when compared to the superoxide anion radical scavenging activity. Specifically, mulberry showed no hydroxyl radical scavenging activity, while the hydroxyl radical scavenging activities of the pear cactus extract were only $47 \%$ and $60 \%$ at 500 and $1000 \mu \mathrm{g} / \mathrm{mL}$, respectively (Fig. 2). Furthermore, even though Korean black raspberry extract was found to contain abundant phytochemicals, Korean black raspberry extracts had hydroxyl radical scavenging activities of only 7 and $3 \%$ at 500 and $1000 \mu \mathrm{g} / \mathrm{mL}$, respectively, which was similar to the scavenging activity of $50 \mu \mathrm{g} /$ $\mathrm{mL}$ that was observed for quercetin standard. As shown in Fig. 1, Korean black raspberry extracts that contained higher total phenolic levels were better radical-scavengers than those with lower phenolic contents $(p<0.05)$. The lack of correlation between the phenolics constituents and the hydroxyl radical scavenging activity may have been due to their various antioxidant constituents, including ascorbic acid, $\alpha$-tocopherol, carotenoids as well as other unidentified compounds $(31,38)$.
(A)

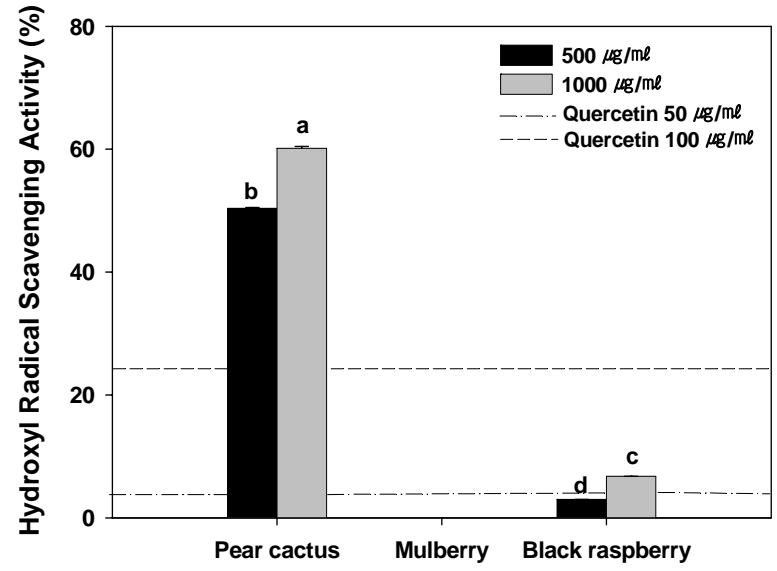

(B)

Control

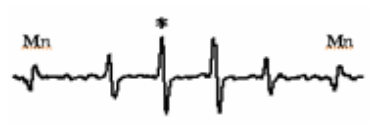

Pear cactus

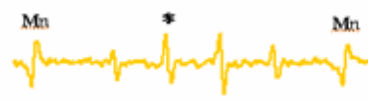

Mulberry

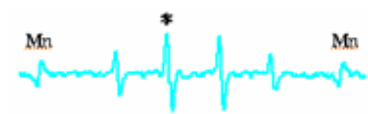

Black raspberry

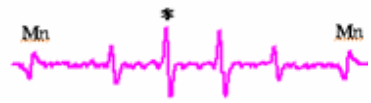

Fig. 2. Hydroxyl radicals scavenging activity (\%) of the ethanolic extracts of fruits at $500 \mu \mathrm{g} / \mathrm{mL}$ as compared to that of quercetin standard $(100 \mu \mathrm{g} / \mathrm{mL})(\mathrm{A})$ and based on electron paramagnetic resonance (EPR) spectra at $500 \mu \mathrm{g} / \mathrm{mL}$ (B). Samples with the same letters are not significantly different (LSD test, $\mathrm{p}<0.05)$. The conditions of EPR analysis: microwave frequency $9.42[\mathrm{GHz}]$, microwave power $5[\mathrm{~mW}]$, modulation amplitude $0.1[\mathrm{mT}]$. Asterisks $(*)$ indicate the peak of DMPO-OH.

\section{SOD-like and nitrite scavenging activity}

SOD-like activity is a typical index used to predict antioxidant capacity, and is primarily used to measure the extent of inhibition of the automatic oxidation reaction of pyrogallol, which reacts with superoxide to form a brown material. As shown in Fig. 3, fruit extracts were found to have SOD-like activity that ranged from $37 \sim 44 \%$ and the activity of Korean black raspberry extract was significantly higher than that of other extracts $(\mathrm{p}<0.05)$.

The nitrite scavenging activity was measured by the ability of samples to remove nitrosamine, which is known to increase the risk of cancer (39). In this study, the nitrate scavenging activities of fruit extracts were evaluated at pH 1.2 and 3.0 (Fig. 4). Both mulberry and Korean black raspberry showed significantly higher activities $(93 \%)$ than pear cactus $(63 \%)$ at $\mathrm{pH} 1.2(\mathrm{p}<$ $0.05)$. 


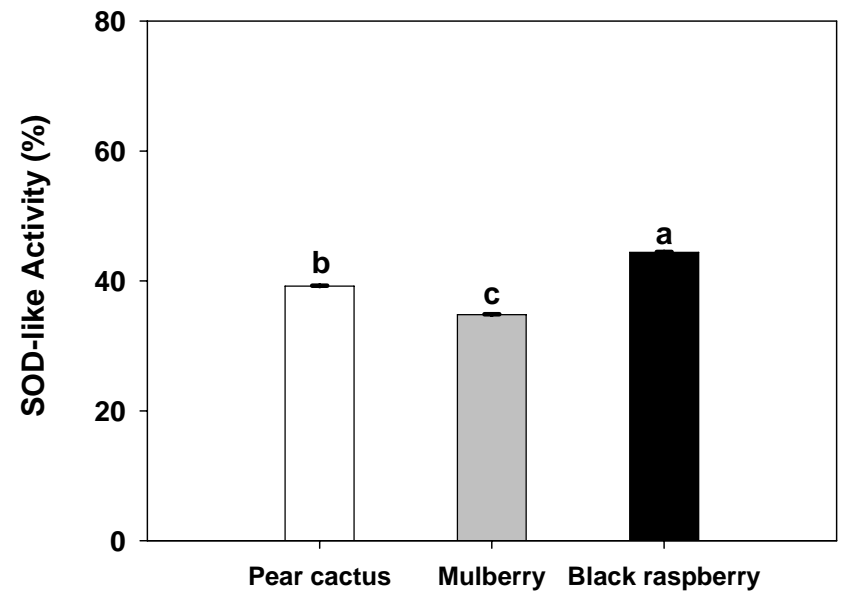

Fig. 3. SOD-like activity (\%) of the ethanolic extracts of fruits. Samples with the same letters are not significantly different (LSD test, $\mathrm{p}<0.01$ ).

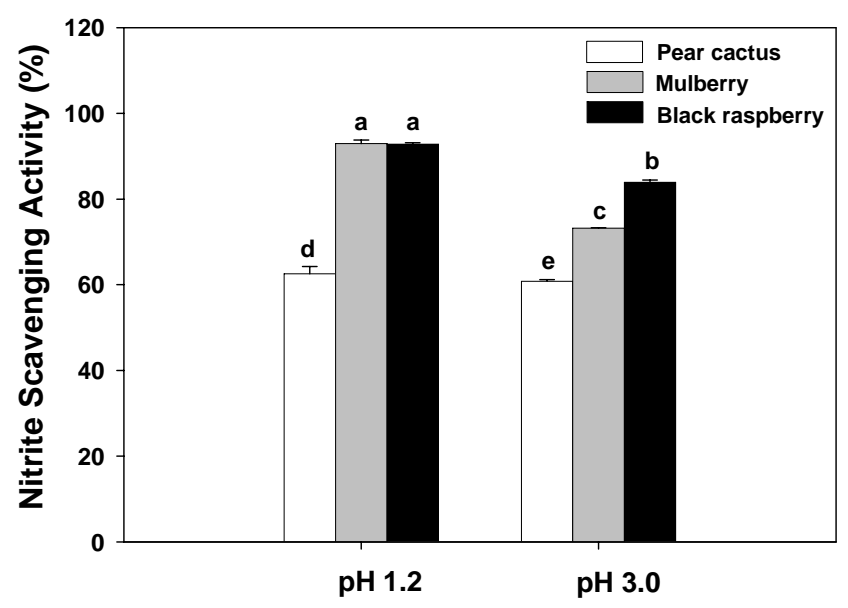

Fig. 4. Nitrite scavenging activity (\%) of the ethanolic extracts of fruits at $\mathrm{pH} 1.2$ and $\mathrm{pH}$ 3.0. Samples with the same letters are not significantly different (LSD test, $\mathrm{p}<0.01$ ).

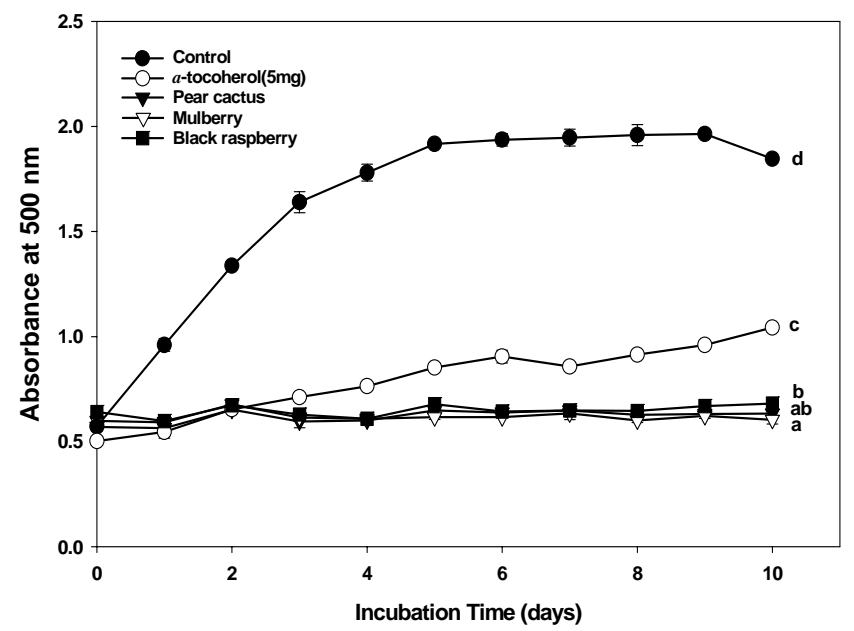

Fig. 5. Lipid peroxidation inhibitory activities of the extract of fruits. Absorbance values represent the means of triplicate analyses of each sample. Samples with the same letters are not significantly different (LSD test, $\mathrm{p}<0.01$ ).

\section{Antioxidant activity of linoleic acid}

As shown in Fig. 5, all samples prevented the reaction of ferrous chloride over 9 days, and each of the samples had activities comparable to $5 \mathrm{mg} / 4 \mathrm{~mL}$ of $\alpha$-tocopherol. In addition, the activities of the fruit extracts were higher than those of $\alpha$-tocopherol $(p<0.05)$. High concentrations of total soluble phenolics or total flavonoids likely play a key role in the retardation of lipid oxidation. In vivo lipid peroxidation has been implicated as the primary cause of many heart-related diseases, atherosclerosis, cancer and aging. Phytochemicals, especially plant phenolics and flavonoids, are becoming a new class of potent antioxidants to address these health-related problems.

\section{CONCLUSION}

Pear cactus, mulberry and Korean black raspberry extracts were evaluated for potential health benefits based on their radical scavenging activity, SOD-like activity and nitrite scavenging activity. The results revealed that all three fruits contained abundant amounts of total soluble phenolics, total flavonoids and total anthocyanins, and the overall antioxidant capacity appeared to be highly correlated with the levels of phytochemicals. The results presented here demonstrate that all three fruits are beneficial to human health and can also be applied to develop various new food products or nutraceutical products.

\section{ACKNOWLEDGEMENTS}

This study was supported by the Department Specialization Fund, 2006, of The Catholic University of Korea.

\section{REFERENCES}

1. Levi F. 1999. Cancer prevention: epidemiology and perspectives. Eur J Cancer 35: 1046-1058.

2. Knekt P, Kumpulainen J, Jarvinen R, Fissanen H, Heliovaara M, Reunanen A, Hakulinen T, Aromaa A. 2002. Flavonoid intake and risk of chronic diseases. Am $J$ Clin Nutr 76: 560-568.

3. Lee KW, Lee HJ. 2006. Biphasic effects of dietary antioxidant on oxidative stress-mediated carcinogenesis. Mech Aging Dev 127: 424-431.

4. Hsu S. 2005. Green tea and the skin. J Am Acad Dermatol 52: 1049-1059.

5. Ramassamy C. 2006. Emerging role of polyphenolic compounds in the treatment of neurodegenerative diseases: A review of their intracellular targets. Eur J Pharmacol 545: 51-64.

6. Chereau-Boudet I, de Chazeron I, Derost P, Ulla M, Lemaire JJ, Durif F, Llorca PM. 2007. Stimulation of the subthalamic nucleus in Parkinson's disease and mood disorders, one-year follow-up. Eur Psychiatry 22: 227-341. 
7. Potter JD. 1997. Cancer prevention: epidemiology and experiment. Cancer Lett 114: 7-9.

8. Zhishen J, Mengcheng T, Jianming W. 1999. The determination of flavonoid contents in mulberry and their scavenging effects on superoxide radicals. Food Chem 64: 555-559.

9. Chen CC, Liu LK, Hsu JD, Huang HP, Yang MY, Wang CJ. 2005. Mulberry extract inhibits the development of atherosclerosis in cholesterol-fed rabbits. Food Chem 91: 601-607.

10. Chen PN, Chu SC, Chiou HL, Kuo WH, Chiang CL, Hsieh YS. 2006. Mulberry anthocyanins, cyanidin 3-rutinoside and cyanidin 3-glucoside, exhibited an inhibitory effect of the migration and invasion of a human lung cancer cell line. Cancer Letters 235: 248-259.

11. Benson L. 1982. Cacti of United States and North America Stanford. Stanford University Press, CA, USA.

12. Shin JE, Han MJ, Lee YC, Moon YI, Kim DH. 2002. Antidiabetic antidibetic activity of Opuntia ficus-indica var. sabotan on $\mathrm{db} / \mathrm{db}$ mice. Kor J Pharmacogn 33: 332336.

13. Park EH, Kahng JH, Paek EA. 1998. Studies on the pharmacological actions of cactus: identification of its antiinflammatory. Arch Pharm Res 21: 30-34.

14. Choi JW, Lee CK, Lee YC, Moon YI, Park HJ, Han YN. 2001. Screening on biological activities of the extracts from fruit and stem of prickly pear (Opuntia ficus-indica). Korean J Pharmacogn 32: 330-337.

15. Choi HS, Kim MK, Park HS, Kim YS, Shin DH. 2006. Alcoholic fermentation of Bokbunja (Rubus coreanus Miq.) wine. Korean J Food Sci Technol 38: 543-547.

16. Kim HJ, Jo CH, Kim HJ, Shin DH, Son JH, Byun MW. 2006. Effects of gamma irradiation on color changes and biological activities of ethanol extract of a mechanically pressed juice of Bokbunja (Rubus coreanus Miq.). J Korean Soc Food Sci Nutr 35: 271-277.

17. Ismail A, Marjan ZM, Foong CW. 2004. Total antioxidant activity and phenolic content in selected vegetables. Food Chem 87: 581-586.

18. Swain T, Hillis WE. 1959. The phenolic constituents of Prumus domestica. I. The quantitative analysis of phenolic constituents. J Sci Food Agric 10: 63-68.

19. Fuleki T, Francis FJ. 1968. Quantitative methods for anthocyanins. 1. Extraction and determination of total anthocyanin in cranberries. J Food Sci 33: 72-77.

20. Jeong JC, Chang DC, Yoon YH, Park CS, Kim SY. 2006. Effect of culture environment and nitrogen fertilization levels on the antocyanin accumulation of purple-fleshed patato (Solanum tuberosum L.) variety jasim. J Bio-environment Control 15: 204-210.

21. Chen H, Zuo Y, Deng Y. 2001. Separation and determination of flavonoids and other phenolic compounds in cranberry juice by high-performance liquid chromatography. J Chromatogr 913: 387-395.

22. Mitsuda K, Mitsuda Y, Kohno M, Hiramatsu M, Mori A. 1990. The application of ESR spin-trapping technique to the evaluation of SOD-like activity of biological substances. Bull Chem Soc Jpn 63: 187-191.

23. Sato M, Ramarathnam N, Suzuki Y, Ohkubo T, Takeuchi M, Ochi H. 1995. Varietal differences in the phenolic contents and superoxide radical scavenging potential of wine from different sources. J Agric Food Chem 44: 80-85.

24. Lissi E, Salim-Hanna M, Pascula C, Castillo MD. 1995. Evaluation of total antioxidant potential (TRAP) and total antioxidant reactivity from luminol-enhanced chemiluminescence measurement. Free Radic Biol Med 18: 153158.

25. Marklund S, Marklund G. 1974. Involvement of superoxide anion radical in the oxidation of pyrogallol and a convenient assay for superoxide dismutase. Eur J Biochem 47: 468-474.

26. Kato H, Lee IE, Chuyen NV, Kim SB, Hayase F. 1987. Inhibition of nitrosamine formation by nondialyzable melanoidins. Agric Biol Chem 51: 1333-1338.

27. Lim JA, Na YS, Baek SH. 2004. Antioxidant activity and nitrite scavenging ability of ethanol extract from Phyllostachys bambusoides. Korean J Food Sci Technol 36: 306-310.

28. Osawa T, Namiki M. 1981. A novel type of antioxidant isolated from leaf wax of Eucalyptus leaves. Agric Biol Chem Tokyo 45: 735-739.

29. SAS Institute, Inc. 1996. SAS Campus Drive. Cary, NC, USA.

30. Lin JY, Tang CY. 2008. Strawberry, loquat, mulberry, and bitter melon juices exhibit prophylactic effects on LPS-induced inflammation using murine peritoneal macrophages. Food Chem 7: 1587-1596.

31. Kuti JO. 2004. Antioxidant compounds from four Opuntia cactus pear fruit varieties. Food Chem 85: 527-533.

32. Lee JY, Moon SO, Kwon YJ, Rhee SJ, Park HR, Choi SW. 2004. Identifiaction and quantification of anthocyanins and flavonoids in mulberry (Mours sp.) cultivars. Food Sci Biotechnol 13: 176-184.

33. Kim HB, Kim AJ, Kim SY. 2003. The analysis of functional materials in mulberry fruit and food product development trends. Food Sci Indus 36: 49-60.

34. Yoon I, Wee JH, Moon JH, Ahn TH, Park KH. 2003. Isolation and identification of quercetin with antioxidative activity from the fruits of Rubus coreanum Miquel. Korean J Food Sci Technol 35: 499-502.

35. Lim JD, Yu CY, Kim MJ, Yun SJ, Lee SJ, Kim NY, Chung IM. 2004. Comparision of SOD activity and phenolic compounds contents in various Korean medicinal plants. Korean J Medicinal Crop Sci 12: 191-202.

36. Bang IS, Park HY, Yuh CS, Kim AJ, Yu CY, Ghimire B, Lee HS, Park JG, Choung MG, Lim DJ. 2007. Antioxidant acitvities and phenolic compounds composition of extracts from mulberry (Morus alba L.) fruit. Korean J Medicinal Crop Sci 15: 120-127.

37. Chang SK, Mun SP. 2008. Antioxidant activities of ethanol extracts from seeds in fresh Bokbunja (Rubus coreanus Miq.) and wine processing waste. Bioresour Technol 99: 4503-4509.

38. Li TSC, Wang LCH. 1998. Physiological components and health effects of ginseng, echinacea, and sea buckthorn. In Functional Foods: Biochemical and Processing Aspects. Mazza G, ed. Technomic Publishing, Lancaster, PA, USA. p 239-256.

39. Lee YR, Hwang IG, Woo KS, Kim DJ, Hong JT, Jeong HS. 2007. Antioxidative activities of the ethyl acetate fraction from heated onion (Allium cepa). Food Sci Biotechnol 16: $1041-1045$.

(Received May 27, 2009; Accepted September 9, 2009) 